\title{
Social Partnership in Vocational Education and Training in Albania
}

\author{
Ejvis (Shehi) Gishti \\ National Vocational Education, \\ Training and Qualifications Agency, Albania
}

\begin{abstract}
In the course of the still ongoing transition process the country has performed major structural and economic reforms. The Albanian economy, the labour market and individuals' aspirations have undergone fundamental changes in the past years. The Vocational Education and Training (VET) system has generally not been in a position to keep pace with these developments. Good practice examples exist only in certain institutions and programmes that have benefited from sustained national, donor and/or private sector support. Numerous analytical and strategic papers have concluded that more systemic efforts are needed at this point to bring VET provision better in line with identified labour market demands. There is no sense of offering education and training for young people or adults, which is of little value for them in terms of becoming skilled workers or progressing on in education to develop higher levels of skills. Within this context, the definition of social partnership in VET is still unclear for both governments and the social partners themselves and is presently not seen as a mechanism for supporting decision making. Social partner organizations are poorly structured to deal with their new roles in VET. A combination of several factors still limits the effective participation in VET systems of social partners. In the conclusions of this study, it is important to know that the governance and decisionmaking capacities of social partners need to be improved, as well as their technical and operational knowledge of the vocational training sector. It is important to ensure that all potential misunderstandings and overlapping functions in this complex plethora of advising bodies are clarified as soon as possible. Careful revision of the roles and responsibilities of social partners that participate in a number of different councils can be a good starting point for acquiring a clear picture of potential overlaps.
\end{abstract}

Keywords: Social Partners, vocational education and training, clarity of roles

\section{Introduction}

\section{Legal and Institutional Framework}

All the countries in the region have enacted laws or regulations to formalize the functioning of social partnership (mostly labour laws and specific by-laws). These regulations define the minimum standards for the responsibility and participation of social partners in employment and VET policies. A variety of legal documents are been developed taking into consideration the principles and practices of social dialogue and social partnership.

It is clear that the legal framework for a partnership between government and social partners is already in place (even though it is still not complete) and that it is not being used in the ways provided for in the different laws and regulations. This may be due to the centralist tradition of government decision making and the still inadequate experience and very weak capacity of the social partners to commit to and sustain engagement in VET policy and decision-making processes, a new field they may sometimes seen as secondary. Nevertheless, several examples indicate that employers have started to become more concerned about the need for a qualified workforce and are looking to initiate joint projects with public institutions with a view to making the VET system more responsive to labour market needs.

The main stakeholders assisting the development of the VET system, are employers' organizations, such as Business Albania, Chamber of Commerce and Industry, Professional associations, etc. Their main tasks include as following: (a) Represent and protect the legitimate economic interests of its members; (b) Promotion of industrial and commercial activities in the country and trade cooperation with other countries; (c) Organizing and managing the marketing of exhibitions and fairs; (d) Consultations; etc. 
Trade unions in Albania are independent organizations of employees workers based on a clear legal basis, but the quality of their organization and their bargaining power is still low. At national level has variety of trade unions, such as Confederation of Trade Unions of Albania, the Union of Independent Trade Unions of Albania, The Union of Banking and Services in Albania, the Union of Trade Unions of Albania, etc.

Public sector includes respective Ministry of Finance and Economy (MoFE) and their respective subordinate bodies in charge for developing VET in Albania (as abovementioned). The MoFE develops policy and legislation in the areas of employment, VET, and the labour environment. The Ministry is the main governmental body responsible for preparing and implementing of educational policies and management of the VET system, including overall resource management of the public VET system and supervision of the non public VET sector.

The National Agency for VET and Qualifications is a subordinate institution of MoFE and its mission is the establishment of a unified VET system at nationally level and internationally recognized. The main functions of the Agency are as follows: developing the national list of occupations and occupational descriptions; developing the national vocational qualification framework and Frame Curricula; accreditation of VET providers; establishment of standards for initial and ongoing training for teachers and trainers; and establishment of student's evaluation and certification criteria. The role of National Agency for VET and Qualifications is highly important for enabling the transparency and recognition of adult learning in Albania and in the same time achieving VET system quality assurance.

The National Employment Service (NES) is an autonomous body under MoFE. The highest decision-making authority of the National Employment Service is the Tripartite Administrative Council with the participation of three employer's representatives, three employees' representatives and seven representatives of the state. The services offered by the NES includes activities like, job matching, career guidance and qualification for the jobseekers; incentives for employers who create new jobs and employ persons with disabilities; and preparation of labour market surveys including SNAs in national level. The NES, as an institution that implements employment policies in the labour market, accomplishes this mission through a network of 36 Employment Offices

Non profit organisations are important components of civil society that support cross-cutting issues such as social inclusion, gender aspects and environmental issues and have an increasing weight in HRD, for example offering informal training and further VET in different occupational fields for special groups, etc.

\subsection{TRIPARTITE BODIES IN ALBANIA}

In Albania, the objective in the field of social dialogue is the encouragement of social dialogue to contribute to improving governance and economic performance. The main legal acts regulating labour relations in Albania are: the Law no. 7961, dated 12.07.1995 "The Labour Code of the Republic of Albania" (amended), and the Decision of the Council of Ministers no. 730, dated 06.11.2003 "On the functioning of the National Labour Council and the appointment of representatives of the Council of Ministers in the Council".

The National Labour Council (NLC) is the highest institutional tripartite structure in Albania and acts as an advisory body to the MoSWY. It is composed of 27 members including representatives of seven related ministries, 10 representatives of employees' organizations and 10 representatives of employers' organizations. The NLC responsibilities and working areas are as following: Social security, health care and pensions; Wages, prices and taxes; Economic and social legislative acts; Employment issues; Occupational health and safety; Issuing its opinions on draft laws, laws and government strategies; etc.

The Tripartite Administrative Council (TAC) is a governing body of the NES and is chaired by the Minister of Finance and Economy. It is composed of representatives of six other ministries, three representatives of employees' organisations and three representatives of employers' organisations.

These two councils are places where businesses can voice their concerns about the needs of the labour force.

The National VET Council is an advisory and tripartite structure in charge of VET coordination among the MoSWY, MoES and other related public and non-public institutions. Its functions and responsibilities include promotion of social dialogue in VET, recommendations on VET policies and strategies, recommendations for harmonization of activities in VET and VET financing. There have been some challenges to the NVETC's functioning, mainly attributed to the unclear role of the technical secretariat, the organisation of sessions, and to some degree a very general and restrictive role related to advising 
the government on VET policy. Currently with amendment of the VET Law (2014) the NVETC is not formally re-established by the DCM.

VET providers boards, which have recently been re-established in all public VET providers, involve directly employers, who currently are actively supporting mainly VET provision in their own working sites for the internships.

In the framework of the CARDS VET 3 project as well as with the support of Albiz Project, (Kulturkontakt), a model for public-private partnership was elaborated and VET teachers were trained to act as coordinators for social partnership (PASOs). Their task is to discuss and establish agreements with local companies in order to facilitate curriculum development with the input of industry specialists, including practical training (internships) for students in the companies. They helped change attitudes towards social partnership, identified businesses for more structured cooperation, and developed networking in the regions where the selected VET schools function.

The employers' and employees' organizations have their representatives in all advisory and decision-making bodies at national and local level such as the National VET Council, National Labour Council and boards of VET providers. However, there is need to further develop a continuing communications with social partners and other stakeholders, in order that social dialogue be developed in all levels- national, regional, local, in all fields of VET organization and implementation (VET policy-making, VET planning, organizing, developing, implementing and monitoring) and especially in missing till now sectoral level.

\section{ANALYSIS OF THE SOCIAL PARTNERSHIP IN VET}

Social partnership in Albania is still in its embryonic stage, although numerous tripartite structures exist in the country. Lack of tradition on a social partnership related with the market economy, too much political dependence, lack of organization culture, high level of segmentation, lack of resources and other factors has weakened the influence of social partners in solving social problems in Albania. Shared decision making does not form part of the traditions and it appears that policies are elaborated by the government. Governments tend to take a very top-down and centralized approach to the governance of such systems, meaning that other bodies have little real role in decision making. Additionally, a large number of social partner representative institutions are not prepared or keen to engage in a field they do not know enough about and one they do not consider to be strategically important. A combination of these elements continues to limit the development of effective education and training systems.

Investments into HRD are not part of the economic strategy of most enterprises. Employers obviously do not see a great need for high quality VET because of low standards of products and services they currently perform that can be done by a workforce with traditional qualifications. The same understanding is characterizing trade unions, also. Similar to other countries in the region, the first initiatives to involve social partners in VET issues are coming from the Government part (with the pressure of donor organizations). National Labour Council was the first tripartite body to establish the social dialogue at the central level.

Regarding VET issues, the partnership was more active at the delivering level. All pilot projects operating in vocational schools and training centres made efforts to establish links with the business in several areas such:

school management (business representatives as members of school boards);

curriculum renovation (business representatives as members of curricula teams);

practical activities for students at the work place in enterprises;

assessment of students competence (business representatives as members of examination commissions);

training of teachers and instructors (contacts with new technology and work processes).

There are no cases of initiatives undertaken by the partners and their participation is not very active. At the end, they have no real influence in the decision making process and in most occasions they are not even informed on what is decided about the issues discussed.

Important issues such as VET levels, types (profiles) and frame-curricula are traditionally considered as strictly governmental "businesses". Regardless of what is described above, many initiatives undertaken by different actors in VET 
during the last 10 years have increased the communication and exchange between VET and labour market in order to improve the quality of vocational qualifications. The most relevant initiatives are:

Introduction of occupational analysis (DACUM approach) as the source of information that helps to define standards, formulate vocational profiles and develop training modules, in the context of course programmes and frame-curricula (initiated by the Swiss Government ISDO Project and the former Institute of Pedagogical Studies - IPS, is currently implemented by other donor projects and National Employment Service - NES). Selected expert workers are directly involved in the occupational analysis process.

Inclusion of selected expert workers in developing occupations and qualification descriptions, curricula, etc.

The designing of the Strategy on Social Partnership in VET in the framework of CARDS Program.

Development of Albanian Qualification Framework with the participation of main stakeholders in this field.

The most common challenge for social partners is their organizational fragmentation. Several trade unions and employer organizations are often in direct competition for influence. Employers or trade unions are not always well organized and there are problems with their representativeness. Their main activity is social dialogue, in which the public authorities usually participate too. Social dialogue encompasses all kinds of negotiation, consultation and exchange of information between the partners.

Meantime, one of the main problems is the low capacity of social partner representatives to engage in policy debates and development. Participation in a meeting is not enough. Social partners should be able to contribute proactively by finding problems to be solved, analyzing government proposals and making counterproposals. People who are nominated to be members of this type of bodies need to know how to represent the interests of their constituencies in a constructive way. Formal consultation is only the first level of involving social partners in policymaking or practical development. A more inclusive way of working should be to invite social partners to contribute to working groups or committees that make proposals for political decision makers. This would allow stakeholders to contribute from the outset, instead of giving them an opportunity to comment already finalized proposals.

\section{CONCLUSIONS AND RECOMMENDATIONS}

Although there is an orientation towards establishing links between education and business, the common view is that there is a persistent divergence between the legislation, policies and enforcement in practice. Apart from a formal participation in national tripartite structures, there are no major initiatives in terms of the practical implementation of VET and business cooperation outside donor projects. Social partners in Albania find it difficult to translate policies into real practice, and the implementation gap is present over the long term. In fact the education and training are traditionally considered (by both government actors and social partners) as the responsibility of 'the state'. It thus appears that despite the many advances that have been made, the underlying logic of governance still entails a high degree of centralisation in terms of government bodies' decision making, and this has an impact on VET and business cooperation. Among social partner organisations and businesses there is s considerable lack of awareness of the need to make VET cooperation a priority.

Social partnership and social dialogue depend on the skills and the resources of their participants. These need awareness of the importance of skills and competences for VET and lifelong learning. They require a profound understanding of VET and its links to the labour market. The overall capacity of social partner organisations depends on the interests and capacity of their elected people and the staff. The capacities of social partners have often been developed in a spontaneous fashion, without being considered an important component of the economic growth of the country. Social partners' limited capacities to engage in meaningful activities are a major obstacle to VET and business cooperation. Far greater effort is needed to turn the principle of social partnership into a real working mechanism, especially at the regional and local levels, as well as the sector level.

All councils regulated within the existing legal framework - NVETC, NLC, TAC, etc - should be made more operational and productive. It is important to ensure that all potential misunderstandings and overlapping functions in this complex plethora of advising bodies are clarified as soon as possible. Careful revision of the roles and responsibilities of social partners that participate in a number of different councils can be a good starting point for acquiring a clear picture of potential overlaps. 
In order to populate the AQF with the relevant qualifications is very important to address a sectoral approach, where the focus is on not just developing qualifications, but ensuring coordinated skills, labour market and socioeconomic policies in particular sectors should also take into account that the professional bodies may play crucial roles. Working with the needs and possibilities, as well as institutional strengths in particular sectors probably has the best chance of success. Social partners, especially employers, have been involved in the development of Albainan Qualification Framework. They can offer an invaluable contribution to the process of translating labour market information into occupational standards, qualifications and even qualifications frameworks. Employers' and workers' organisations can also offer important contributions to the development of learning outcomes for qualifications. Businesses have a key role to play in the assessment of skills needs, and should be actively involved in this initiative. An efficient and effective mechanism for articulating periodic training/qualification needs in predefined economic sectors should be the establishment of the respective sectoral committees with the representatives from businesses, unions, VET providers, universities etc. These organisms will link better labour market demands with VET system. Involvement of social partners in VET depends on the structures of cooperation and the legal frameworks that support these. Social partners can play a role if there is room for their contribution. Therefore, sector committees are needed. These can be effective cooperation platforms if they have the required mandate and means. These structures need to be recognised through appropriate legislation that gives them authority. They need resources (e.g. a secretariat) to successfully perform their tasks.

The governance and decision-making capacities of social partners need to be improved, as well as their technical and operational knowledge of the vocational training sector. A peer learning methodology could be used for this, also involving government services. Pilot projects and good practices should be identified and shared. Two kinds of competences are needed to help social partners play an active role in VET: policy and decision-making skills (through formal representation of elected members) and technical skills (with staff dedicated to supporting the decision makers). As regards selection of board members, priority should be given to those who are convinced of the value of HRD. These individuals should be knowledgeable about policies and strategies in the field and to some extent should be the owners of the social partners' strategies. Technical staff are expected to provide permanent support to the decision makers by supplying them with updated information, preparing briefing notes and reports, organising relationships with other partners, drafting papers, organising interventions by technical teams in discussions and workshops, and so on. 